\title{
INTELEKTUALAC DANAS \\ Predgovor
}

\section{Drago Roksandić i Ivana Cvijović Javorina}

I.

esničini susreti zaključili su 2013. godine raspravom na temu "Intelektualac danas" višegodišnji niz svojih skupova posvećenih intelektualcima u 20. stoljeću. ${ }^{1}$ Zaključnom raspravom Pripremni odbor samo je prividno odstupio od svojega programskog načela da će se na Desničinim susretima raspravljati o temama koje proistječu iz kritičkog propitivanja opusa Vladana Desnice. Kažemo "samo prividno" jer je Desnica - kada je o njegovu književnom djelu riječ - živ pisac, kao što se više puta očitovalo posljednjih godina. Intelektualna kultura njegova artizma u načelu je neupitna, a nova čitanja njegovih ključnih djela (Zimsko ljetovanje, Proljeća Ivana Galeba, Pronalazak Athanatika itd.) istovremeno su i doprinosi raspravama o smislu umjetničkog i intelektualnog stvaralaštva i javnog djelovanja "danas i ovdje".

Bez namjere da "endistički" proglašavamo kraj "Doba intelektualaca", koje obično koincidira s "kratkim" dvadesetim stoljećem (1914./1918. - 1989.), cilj Desničinih susreta 2013. bio je kritički propitati je li održivo mišljenje da se "Doba intelektualaca" podudara, s jedne strane, s "Dobom netrpeljivih" ili "Dobom ekstrema", a s druge strane s "Dobom promjena", te kakvo je značenje jedne i druge interpretacijske matrice za raspravu o fenomenu intelektualaca u 20. stoljeću, o njihovim angažmanima ili dezangažmanima, očitovanjima ili šutnjama, konformizmima i nonkonformizmima itd. U stoljetnoj perspektivi nesumnjivo je silno rastao broj ljudi koji su po bilo kakvoj definiciji bili intelektualci. Bitno je danas ne previdjeti da taj rast nije bio linearan jer su intelektualci nerijetko bili najveće žrtve ratnih ludila 20. stoljeća. Po svjetonazorskim, etničkim ili konfesionalnim kriterijima stradavali su mnogobrojni intelektualci. Međutim, intelektualci su istovremeno po istim tim i drugim kriterijima bili i akteri - u cijelome rasponu mogućih odgovornosti - jezivih zločina koji su počinjeni u 20. stoljeću. Dakle, kritičko propitivanje fenomena "intelektualac danas" ne može biti aprioristički reducirano u bilo kom pogledu. Nadamo se da prilozi prikupljeni u ovoj knjizi o tome dovoljno sugestivno svjedoče.

Usp. programske knjižice Desničinih susreta 2009., 2011., 2012. i 2013. godine (http://kula-jankovica.unizg.hr/hr/ desnicini-susreti/izdanja-centra/programske-knjizice/) i zbornike radova u kojima su objavljeni tekstovi nastali na temelju priopćenja s tih skupova (http://kula-jankovica.unizg.hr/hr/desnicini-susreti/izdanja-centra/biblioteka-ds/). 


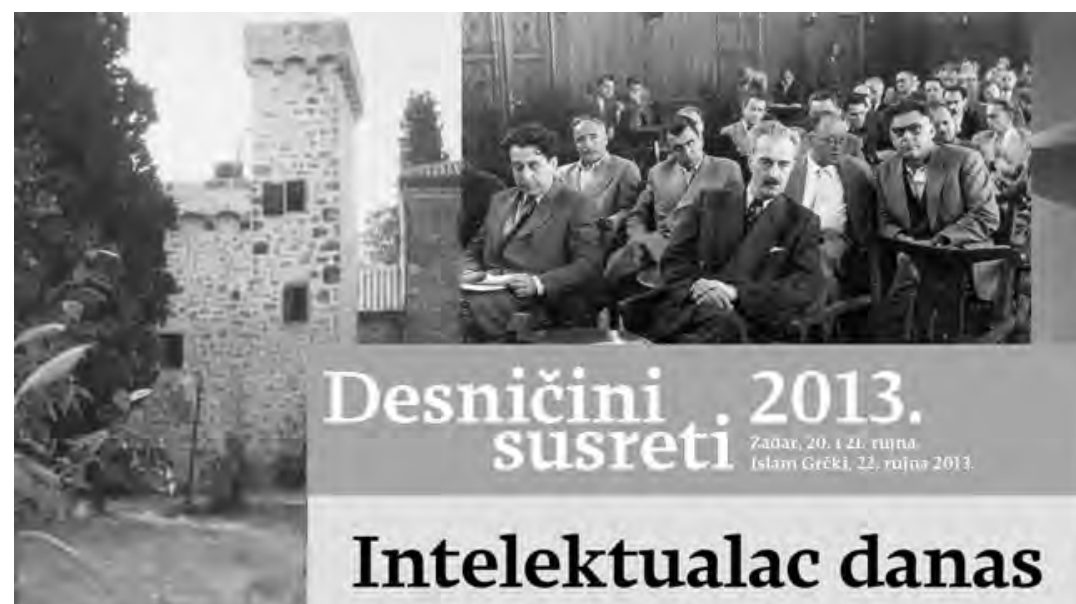

SUDIONICE I SUDIONICI "DESNICINIH SUSRETA 2013."

VEADAN DESNICA U ZADRU I ISLAMU GRCKOM

OLUPINE NA SUNCU

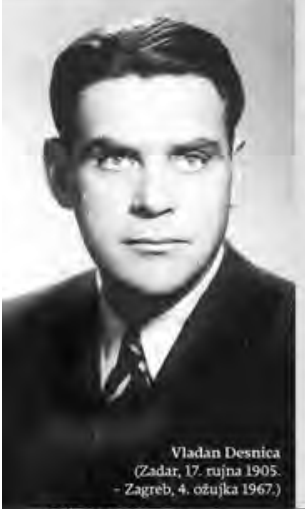

Velimir Visković (Zagreb), Vjeran Zuppa (Zagrb), Josip Rastko Močnik (Ljubljana), Losoncz Alpảr (Novi Sad), Cvjetko Milanja (Zagreb), Hilmo Neimarlija (Sarajevo), Christian Promitzer (Graz), Miranda Levanat-Peričić (Zadar), Ivana Latković (Zagreb), Božo Repe (Ljubljana), Tonko Maroević (Zagreb), Helena Peričić (Zadar), Tatjana Rosić nlić (Beograd), Zvonko Kovač (Zagreb), Bojan Đorđević (Beograd), Virág Zoltán (Segedin), Drago Roksandić (Zagreb), Ivana Cvijović Javorina (Zagreb), Branimir Janković (Zagreb), Boris Bui (Zagreb), Filip Šimetin Šegvić (Zagreb), Nikolina Šimetin Šegvić (Zagreb), Ivan Radenković (Novi Sad), Vladimir Gvozden (Novi Sad)

PRPREMILI บ ИL PODUPRL:

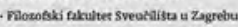

Centas za komparativanhistorijiske i interkuleurne studije

Odsick a k kroutistik

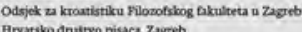

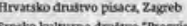

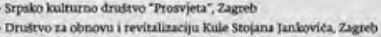
- Gradska ured za obrazovanje, kulturu i fport Gradia Zagreba - Ministartwo kulture Republike Hivatse - Sveutilitse u Zadru

t Ured a nacionalne manjine Vlade Republike Hrvatske
PROGRAM RADA

Zadar, petak, 20. rujna 2013. godine, otvaranje "Desničinih susreta 2013." od 09:00 do 09:30 (Rektorat Sveućilista u Zadru, dvorana 2.3, II. kat, Ulica Mihovila Pavlinovica bb)

Zadar, petak, 20. rujna 2013. godine rasprava od 09:30 do 13:00 (Rektorat Sveucilista u Zadru, dvorana 2.3, II. kat, Ulica Mibovila Pavlinovica bb)

Zadar, petak, 20. rujna 2013. godine, rasprava od $15: 00$ do $18: 30$ (Rektorat Sveucilista u Zadru, dvorana 2.3 II. kat, Ulica Mihovila Pavlínovića bb)

Zadar, petak, 20. rujna 2013. godine, večernji program: Dua pogleda na poetski opus Vladana Desnice od 20:00

(Gradska knjitznica Zadar, U. Stjepana Radica 11)

Zadar, subota, 21. rujna 2013. godine,

rasprava od 09:00 do 11:00 (Rektorat Sveucilista u Zadru, dvorana 2.3. II. kat, Ulica Mihovila Pavlinovica bb)

Zadar, subota, 21. rujna 2013. godine, predstavljanje izdanja od 11:30 do 13:00

(Gradska knjiżnica Zadar, UL Stjepana Radica II)

Zadar, subota, 21. rujna 2013. godine,

rasprava od 15:00 do 18:30 (Rektorat Sveucilista u Zadru, dvorana 2.3, II. kat, Ulica Mihovila Pavlinovica bb)

Nedjelja, 22 rujna 2013. godine Kula Stojana Jankovića u Islamu Grčkom

\section{$\gg$ Migud $\ll$}

(swest onedije)

$$
\text { (Coribuireus ti }
$$$$
\text { ca... vir izi ing }
$$
cosictur
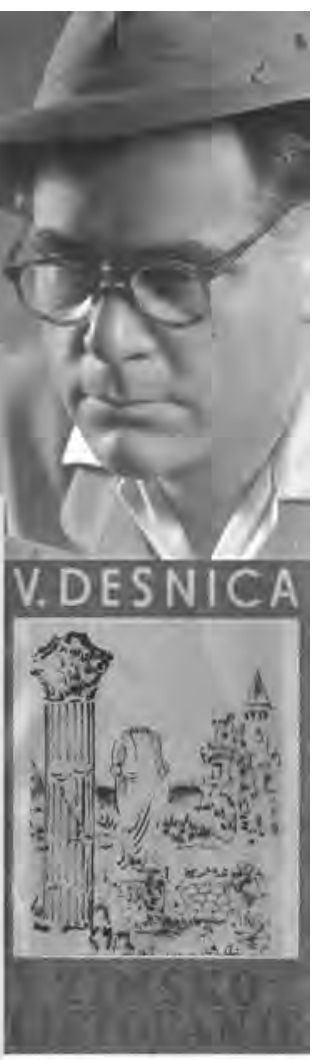

Pisite staromodno! - Staromodno mote da postane samo ono sto je nekad bilo pomodna Prema tome ne źelite li postati staromoda ne pisite pomodno! Písućí staromodno, radite za osiguranje svoje (knjizevne) starosti! Pisite staromodnol I pri tome dobro pazite da vam se, u razmatranjima o totne pitanju, pod pojmom modernog ne podvuce pomodno! Primjeri koji to potkrepijuju strahovito su mnogobrojni; ijedno obilije izbora stvara u covjeku zubunu zoijm primierom prog da posegne Kad primjere Kontrapunkt" (kojim smo se neka toliko odusevljavalii), kakvog ti razocaranjal A, s druge strane, kad precitavamo koju stranicu Goncarova, iz dobrog starog Oblomova, (koji je valjda i u vrijeme

kad je napisan zvucao malko, malko staromodno), kako ti je malo ili nimalo popustio od vremena kad smo ga prvi put uzeli u ruke, jos negdje stedinom gimnazije! nemojte sami sebe obmaniivati postulatima noveg vrement zahtjevima publike itd: uprav je zabrinjujuća naklonost koju uzivaju kod publike "staromodni" pisci: Dickens, Balzac, Tolstoj i sliéni. Da, Dickens, Balzac, Tolstoj i slični. Da,
staromodnost je naliçe pomodnosti. staromodnost je nalicje pomodn tuána starost pomodnosti. A kako moda i pomodnost nisu prave estetske kategorije, to je jasno da staromodnost ne pogada istinski umjetnicka djela, odnosno pogadia samo one nifhove dijelove koji predstavljaju nižu i ne punu

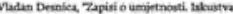

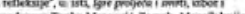
2008, 477-478 Zapies su privi pat otiontioni 


\section{II.}

O pozivnom pismu za Desničine susrete 2013.: Intelektualac danas Pripremni odbor slobodno se može reći - raspravljao je vjerojatno s više kritičkog žara nego prethodnih godina. Konačna formulacija teme, koju je inicijalno bio predložio prof. dr. sc. Zvonko Kovač, prihvaćena je nakon nekoliko sastanaka. ${ }^{2}$ Izoštrenost sadržaja doprinijela je tomu da se relativno lako mogao dogovoriti sastav sudionika koji je unaprijed jamčio kvalitetna priopćenja, sadržajnu raspravu na skupu i, na koncu, kvalitetne članke u Zborniku. Čitatelji ovog izdanja, dakako, u konačnici će dati najmjerodavniju ocjenu postignutoga. Iako je pozivno pismo dostupno na nekoliko mjesta, ${ }^{3}$ neće biti suvišno reproducirati ga u većem dijelu kao svojevrsni vodič u čitanju Zbornika:

(...) Od Zolina J'accuse do "smrti" intelektualnog angažmana kakav je simbolizirao Jean-Paul Sartre te suvremenih intelektualnih kontroverzi u epohi globalizacijskih izazova u vezi sa sadašnjošću i napose budućnošću ljudske vrste i svijeta, ne prestaje biti upitno što je intelektualac te što očekivati od intelektualacâ i koliko su ta očekivanja opravdana. Prvo je pitanje s time u vezi sljedeće: ako se moderno društvo ne može (re)konstituirati onkraj svojih racionalističkih i prosvjetiteljskih ishodišta, je li moguće govoriti o povijesnoj istrošenosti pojma "intelektualca"?

Svjetski trijumf liberalizma 1989. godine nije označio početak kraja povijesti (Francis Fukuyama), ali je neoliberalno globalizirao svjetsku politiku i gospodarstvo pa i kulturu na načine kojima su Sjedinjene Američke Države, Europska unija, Rusija i Kina, odnosno, sva moderna društva postala svaka na svoj način zatočenici međusobno isprepletenih upitnih interesnih imperativa. Pri tome su potraga za ljudskim boljitkom i srećom prije instrumentalni surogat nego bilo što drugo, a budućnost svijeta kao ekosistema krajnje dvojbena.

Ključno je pitanje što se mijenja, slijedeći Pierrea Bourdieua, u funkcioniranju suvremenoga društvenog, političkog, kulturnog, znanstvenog i intelektualnog polja, napose kada je riječ o promjenama u vezi s medijskim konstruiranjem zbilje, mehanizmima "mikrofizike moći" (Michel Foucault) te obličjima raznolike prisutnosti ideologije u "postideologijskom dobu". Dakle, neizbježno je usmjeriti se $\mathrm{k}$ analitičkim propitivanjima suvremenog intelektualnog polja i sistemskoj analizi koja uvjetuje njegovo funkcioniranje, izbjegavajući povijesno iscrpljene tradicijski baštinjene bifurkacije na "ljevicu" i "desnicu", odnosno poimanje "progresa" i "regresa" u povijesti.

Je li nakon tzv. smrti figure univerzalnog intelektualca sartreovskog tipa vrijeme za specifične intelektualce koji će, slijedeći Foucaulta, intervenirati u političkoj borbi kao znanstvenici eksperti u svome fahu. Obrazovanih je u globaliziranom svijetu inače sve više, mogućnosti njihove međusobne komunikacije su sve veće, znanje je sve važnije, a sve je upitnije tko je i što je intelektualac te što je uopće moguće očekivati od njega u svijetu u kojem je i on više ili manje prepoznatljiv pojedinac na tržištu radne snage (u biti neovisno o svome intelektualnom elitizmu, što god to danas moglo značiti). Što nam, nasuprot ovakvu pristupu, poručuje Konrad Liessmann u svojoj Teoriji neobrazovanosti?

$2 \quad$ Pisane obrazložene prijedloge koncepcije pozivnog pisma i konkretnih formulacija dali su (abecedno): Ivana Cvijović Javorina, Branimir Janković, prof. dr. sc. Zvonko Kovač, prof. dr. sc. Nikola Petković, prof. dr. sc. Drago Roksandić, Filip Šimetin Šegvić i Nikolina Šimetin Šegvić.

3 Usp. Drago Roksandić - Filip ŠImetin Š Egvić - Nikolina Šimetin ŠEgvić (ur.), Desničini susreti 2013. Intelektualac danas. Program rada / sažeci izlaganja, Zagreb 2013., 9-10 i http://kula-jankovica.unizg.hr/hr/desnicini-susreti/odesnicinim-susretima0/desnicini-susreti-2013/. 
Pitanja s time u vezi otvorena su u dugome povijesnom trajanju, najjasnije već od prosvjetiteljskih prijepora, napose u Jean-Jacquesa Rousseaua, a i danas su aktualna, primjerice u misli Michel de Certeaua. U 20. stoljeću Antonio Gramsci ne razlikuje intelektualca od radnika (homo sapiens = homo faber), a Edward Said izričito tvrdi da intelektualac po definiciji mora biti sekularan. Hans Küng etička pitanja monoteističkih religija vidi unutar istog intelektualnog obzora. Što o tome danas možemo reći kada se nakon posljednjega, sekularnog hladnog rata, koji je završio u 1990-ima, suočavamo s novim usponima kako sekularizacije tako i globalnih religijskih fundamentalizama.

Još se nisu do kraja razjasnile razne dubioze, nepravde i nedjela prošlosti, a već su nas sustigla nova nedjela i nove nepravde ratne i tranzicijske stvarnosti, pri čemu je uloga i moć intelektualaca sve dvojbenija i slabija. U nekom smislu njihova se drugost/stranost u odnosu na vlastito društvo ili polje djelovanja osjeća kao prijetnja većinskim politikama, etničkim ili vjerskim strategijama, pa i demokratskom razvoju. Upravo suprotno, prije nekoliko godina proklamirani interkulturni dijalog, kao temeljna vrednota EU, nije trebao uputiti na međusobnu suradnju samo intelektualce, umjetnike i znanstvenike različitih kultura i socijalnih predispozicija, nego i afirmirati interkulturalnost kao vrijednost koja čuva dostojanstvo osobe i pojedinca, budući da ona razvija toleranciju prema drugom i drugačijem, što je zapravo uvjet za opstanak demokratskih odnosa u društvu. Briga i odgovornost za drugoga tako se u slučaju intelektualaca danas zapravo javlja kao zabrinutost nad vlastitom sudbinom i ulogom u društvu.

Iako se u već više od pola stoljeća u procesima intelektualizacije ljudskog rada i stvaralaštva zbiva "rodni obrat", o njemu se vrlo malo raspravlja. Zašto je tome tako? Pored toga javljaju se i vrlo aktualna pitanja intelektualaca između egzila i azila - načini suvremene emigracije i oblici interkulturne književne i umjetničke djelatnosti i djelovanja; kao posebne teme mogu se izdvojiti reprezentacija intelektualca u književnosti tranzicije, intelektualci i virtualni svijet, interkulturni dijalog kao interdisciplinarni, socijalni i međuvjerski fenomen itd.

Uredničke marginalije, skupljene u ovom Predgovoru, nemaju namjeru vrednovati uvrštene priloge. Velik napor, i to sa zadovoljstvom, bio je uložen u ugovaranje priopćenja. U tome su najveći udio imali supredsjedatelji Pripremnog odbora, prof. dr. sc. Zvonko Kovač i prof. dr. sc. Drago Roksandić, te tajnici Filip Šimetin Šegvić i Nikolina Šimetin Šegvić. Ništa manji nije bio napor uložen u prikupljanje autorskih članaka u skladu s dosadašnjim uredničkim standardima. ${ }^{4} \mathrm{~S}$ novostečenim uredničkim iskustvom u obradi članaka iznova se nametnula potreba, kao i u prethodnom Zborniku Intelektualci i rat 1939. - 1947., artikulirati uredničke impresije u obliku Predgovora. Prije svega tako treba čitati nastavak ovoga teksta. Prilozi su uvršteni prema redoslijedu izlaganja, a tako su složene i uredničke bilješke uz pojedine tekstove.

\footnotetext{
Zahvaljujemo članovima Pripremnog odbora koji su pomogli pripremiti ovaj zbornik za tisak, posebno supredsjedatelju Desničinih susreta 2013. prof. dr. sc. Zvonku Kovaču i tajnicima Filipu Šimetinu Šegviću i Nikolini Šimetin Šegvić. Našu veliku zahvalnost zbog svojega već provjerenog doprinosa u završnoj etapi zada na zborniku zavređuje Plejada d.o.o., tj. njezin glavni urednik Ilija Ranić, urednik dr. sc. Vladimir Filipović i lektorica Sara Bertičević. Sa zahvalnošću ističemo da je objavljivanje ovog zbornika omogućeno sredstvima europskog projekta Kula Jankovića: spomenik kulture, pokretač održivog razvoja Ravnih kotara, koji vode Sveučilište u Zagrebu i Ministarstvo znanosti, obrazovanja i sporta Republike Hrvatske. Desničini susreti su jedna od aktivnosti spomenutoga europskog projekta. Zahvaljujemo i projektnoj menadžerici Andrijani Jurić što je u finalnoj fazi projekta olakšala realizaciju ovog zbornika. Posebno nas je zadužila Ana Pojatina, osmislivši vizualni identitet Desničinih susreta i dizajniravši logo, koji se prvi put objavljuje u ovoj publikaciji. Zahvaljujemo na potpori Ministarstvu kulture i Ministarstvu znanosti, obrazovanja i sporta Republike Hrvatske.
} 


\section{III.}

U "dokoličarskom" razgovoru pjesnik Simonid, "učeni čovjek", "govori $o$ tiraniji $u$ tiraniji, a pred tiraninom". Nastoji potaknuti tiranina Hijeronta da prihvati njegovo shvaćanje idealne tiranije. Hijeront kaže Simonidu da tirani "poznaju ljude neustrašive, vješte i pravedne", no da mu se "čini najvećom bijedom priznavati da ima ljudi od vrijednosti, a biti prisiljen služiti se drugima". Vjeran Zuppa u svojemu prilogu Intelektualac: glasine o Subjektu (dvanaest marginalija, a trinaesta je umjesto zakljucka) referira se u prvoj marginaliji na Simonidov dijalog s Hijerontom da bi otvorio pitanje kako "intelektualca jučer" tako i "intelektualca danas", ali i "intelektualca sutra": Hijerontovo "biti prisiljen služiti se drugima, a ne vrijednima (...) prisut(no) je do danas, gdje je nezaobilazni modus operandi u totalitarnim sustavima, partitokracijama, ali i u takozvanim 'mladim' demokracijama". Zuppin pristup zadanoj temi nije ahistorijski jer je riječ o akterima i strukturama dugog trajanja u europskoj povijesti. Uostalom, postavljajući problem, Zuppa slijedi Alexandrea Kojèvea, za kojega je Simonid "učeni čovjek" i "pjesnik", tj. "tipični intelektualac”. Simonid je, naime, prvi registrirani pjesnik u grčkoj tradiciji koji s jednim vladarom, tiraninom, raspravlja o vladavini. Kako filozof, najpozvaniji govoriti o vladavini, da bi bio filozof, ne može biti vladar, a vladar, da bi bio vladar, ne može biti filozof, prema Kojèveu, ostavljeno je "plejadi intelektualaca svih odlika (koja je više ili manje rasprostranjena u vremenu i prostoru) na brigu da - na teoretskome planu - približi filozofske ideje političkoj realnosti”. Zuppa je mišljenja da ovakvim stavom Kojève "izlazi iz polja ekskluzivne interpretacije Ksenofontova teksta te pri tome, $s$ nešto sasvim vidljive ironije, ulazi u suvremenost i njime ujedno referira i položaj europskog intelektualca unutar političke zbilje dvadesetoga stoljeća”.

Time Zuppa definira problem intelektualca danas u povijesnoj perspektivi slično tomu kako će to učiniti Alpár Losoncz u svojemu prilogu u ovome zborniku. Ipak, polazi od drugačijih pretpostavki: "Pjesnik Simonid definiran je kao lik koji u Ksenofontovu dijalogu jasno pokazuje osnovnu strukturu svojega funkcioniranja. Ta je struktura transformativna, jer je akterska. Ona je autorska, jer radi na učinak diskursa. Pri tome je ona i determinativna, jer samomu liku, kao takvomu, više pripada determinacija nego identitet." Iznova referirajući na Kojèvea, Zuppa kaže da je to lik kojemu "pripada da filozofske ideje 'približi' političkoj realnosti. Štoviše, da ih 'prilagodi za primjenu'. (...) Premda, dakle, još od samih početaka intelektualac nastupa na planu koji primarno nije meditacijski nego je medijacijski, počelo se tada dovršavati razdoblje, a u kojemu su, kako to duhovito formulira Sartre, 'unuci filozofa postali intelektualci' (: les petit-fils des philosophes sont devenues les intellectueles)." Ako je doista riječ o "modelu koji istječe" (H.-P. Müller), ključno pitanje "zašto?" Zuppa postavlja tako što problem strukture intelektualnoga diskursa raspravlja s obzirom na njegovu "jučerašnju” i "današnju” povezanost sa "stanjem" filozofije i "stanjem” politike, jer je jedino na taj način moguće odgovoriti na primarno pitanje "koji su izvori legitimiteta i autoriteta intelektualca". Izlazeći iz razdoblja modernih vremena u kojemu je "do kraja bila u-ozbiljena relacija: mišljenje - akcija" te u kojemu je vladala kratica "sve je politika", načelima "dekonstrukcije" doveden je u pitanje "subjekt" - naglašava Zuppa - "koji u svojem transcendentalnom, 'praznom identitetu' (M. Foucault) tijekom čitave povijesti pokriva, pa i prepokriva, čitavo njezino polje događajâ. Dakle, ususret intelektualcu, u vremenu postmoderne, moglo bi se reći, ide ono što Kristeva naziva le sujet destabilisé." Međutim, "subjekt" je poljuljan i zbog toga što mu ni današnje "stanje" filozofije, a ni današnje "stanje" 
politike ne ide na ruku. Slijedeći Alaina Badioua, autor kaže da suvremena filozofija daleko više pripada mnijenju negoli mišljenju: "Najviše prostora za sebe pronašla je, naime, u žurnalizmu, u 'javnim kozerijama' o svemu i svačemu." Badiou se izjašnjava, što je i Zuppino stajalište, protiv "prenemaganja” o kraju filozofije. Riječ je o njezinoj "rekvalifikaciji” i "rekonstrukciji”: "Događaj je jedan od središnjih pojmova njegove ontologije. Uz događaj vezuje i ponovno utemeljenje teorije subjekta. U pozadini Badiouove ontologije jest postavka o "neprekidnome postojanju filozofije". Kritički vrednujući marksističko iskustvo 20. stoljeća, ali i iskustvo Heideggerove identifikacije s nacizmom, Zuppa se referira i na recentni Habermasov stav navodeći da "utopijsko mišljenje izgleda ima zadaću otvoriti alternative djelovanja”. Budući da je demokracija danas u Europi - prema Žižeku - "zapravo, administrativni projekt", k tomu projekt bez "ideološke strasti”, tj. slijedeći Don Watsona, Zuppa tvrdi da je došlo do "raspada javnog jezika" te da politika već posvuda govori "upraviteljskim žargonom", "mehaniziranim diskursom” koji "ukida potrebu za razmišljanjem" i zaključuje: "Tragom ove postavke, današnji intelektualac - ako hoće (ima volju) misliti o politici i njezinu diskursu - nalazi se, između ostaloga, u situaciji da razmišlja o nečemu što upravo ukida potrebu za razmišljanjem. Antikno, diderotovski, to bi se danas moglo zvati: paradoks o intelektualcu." Jedan je od ključnih autorovih zaključaka sljedeći: "U kontekstu te borbe za nove oblike mišljenja i djelovanja, a istodobno života unutar metafizičkog konteksta, intelektualac i opet ima svoju priliku. Prvenstveno zato što je lik koji je - onomad posredujući, a jučer sudjelujući - izgradio vlastitu biografiju na svojemu coagitare. Mogućnosti da 'skupa protrese' strane koje se opiru dijalogu."

U Moći i nemoći intelektualca Alpár Losoncz, uspoređujući rasprave sv. Augustina s Pelagijem i rasprave među intelektualcima danas, polazi od pretpostavke da, primjerice, pitanja istinitosti i smisla traganja za istinom podliježu povijesnim promjenama. Koliko god fokusiranje na status riječi i ideja bilo bitno za razumijevanje pozicije intelektualaca u suvremenome društvu, ono je neizvedivo bez analize socioekonomskih tendencija, kao i bez analize transformacije diskurzivnih mogućnosti korištenja riječi i ideja, neophodnih za konceptualizaciju stvarnosti. Kada se radi o performativnosti riječi, Losoncz ističe da je ona "duboko utisnuta u moderno samorazumevanje: na ključnim stranicama Hobbesovog Levijatana ćemo naći dokaz za delotvornost reči umetnutu u konstitutivnu fikciju moderniteta, naime, u sklapanje ugovora. Jer, čitamo: 'kao da je svako rekao svakome'." Otvarajući pitanje o odnosu intelektualaca prema riječima, autor kontrastira Straussov pristup klasičnim piscima u njihovu dobu (“(...) klasični pisci mogu [se] razumeti samo ako ih čitamo između redova: oni su uvek uzimali u obzir da postoji cezura između istine i mnenja, ali su smatrali da se istinom mogu adresirati samo oni čitaoci koji su dovoljno razumni da podnesu istinu. Intelektualac koji stupa na scenu da izdejstvuje učinak reči pojavljuje se pred nama uvek u maski (...)”) s Foucaultovim shvaćanjem govorenja istine u demokraciji (“(...) kako govoriti istinu u demokratiji gde je pritisak konformizma ogroman. Odatle njegov (tj. Foucaultov nap. ur.) termin koji treba prevesti u današnjicu: hrabrost da se govori istina (...)"). Pitanje hrabrosti govorenja istine za Losoncza je tim važnije što intelektualac, propitujući i tumačeći vlastitu poziciju, neizbježno zadire u ključnu svjetsku problematiku: "Zapravo, intelektualac ne samo da je ukotvljen u napetosti između partikularizma i univerzalizma (uostalom kao i svi u modernitetu) nego on/ona neprestano reflektuje na ovu tenziju. (...) Teško je osloboditi se od moralističkih značenja koja kruže oko intelektualca: skloni smo da brzo potežemo argument izdaje (...) Valja se pre upustiti u strpljivo razmatranje različitih relacija $\mathrm{i}$ isprepletenosti između aktivne i pasivne pozicije, autonomije i heteronomije intelektualaca 
(...)." Konkretna intelektualnohistorijska analiza, koju autor argumentirano zagovara kada je riječ o "intelektualcu danas", nužno ga vodi i k eksplicitnoj formulaciji pitanja o njegovoj intelektualnoj odgovornosti: “(...) kada se postavlja pitanje konverzije onih intelektualaca koji su nekada zagovarali marksizam kao garant emancipacije za vreme socijalizma, a posle su započeli žestoko odbacivanje istog, postajemo nemušti i jedva da uspevamo nešto da kažemo. Vladajući oblici tumačenja sugerišu da je posle pogrešnog razumevanja emancipacije reč zapravo o povratku na normalne putanje. Zalutali smo, ispali smo iz evolucijskih tokova istorije, ali se vraćamo na pravi put. Realizatori velikih intelektualnih konverzija su deo toga. Utoliko odgovornost intelektualca za izrečene reči postaje neizvediva." Na stranu pitanja o tome kakav je tko kada marksizam zagovarao i koliko je to što je tko zagovarao bio / nije bio marksizam ili, nasuprot tomu, kakav tko liberalizam danas zagovara, kako je do njega došao i do čega je ustvari stigao! Važnije je postaviti pitanje zašto bi intelektualci danas trebali biti odgovorniji nego pripadnici bilo koje druge elitne skupine koji su također u nekoj prošlosti zagovarali marksizam ili bilo koju drugu ideologiju onkraj liberalizma, a da to danas u biti nikome nije sporno. Da ne govorimo o marksizmu radnih slojeva, "srednjih klasa" itd., itd. Isticanjem posebne odgovornosti intelektualaca u biti se priznaje upravo ono što se danas hoće osporiti, a to je relevantnost ideja, otvoreno pitanje ideologija u proklamiranom postideologijskom dobu itd. Losoncz se posebno zadržava na Hayeku, po mnogima ključnom misliocu neoliberalizma: "Hayek posebno izdvaja filozofe i (...) čak i kod ekonomista uvek istražuje filozofske ambicije: tek filozofi među intelektualcima krče put idejama, tek oni daju idejni polet obuhvatnom zahvatu sveta. (...) On (Hayek - nap. ur.) ne kaže u stilu nekih komentatora da je posredi 'suton intelektualaca' i ne slika u stilu Lyotarda grob za univerzalističke intelektualce, nego ih ističe kao istinski nezamenljive. Pri tome, on jasno prepoznaje one intelektualce koji programatski uobličavaju ideje: nigde on ne spominje ideologiju, ali je jasno da nas spoj između ideja (koje potiru kultne ideje socijalizma, a koje nipodoštavaju potencijale slobode) i logosa vodi do momenta ideološkog usmeravanja. (...)" Za raspravu o "intelektualcu danas" važno je i Hayekovo razlikovanje "filozofa" i "profesionalnih secondhand dealersa": "Postoje 'filozofi' za njega, dakako, ne u smislu profesije nego stratega koji nameću put za društvo. I postoje tumači koji će u okviru njihovih materijalno-institucionalnih praksi sprovesti ideju u delo, odnosno realizovaće rituale prevoda bez čega ideja ne može da bude delotvorna. (...) To su intelektualci koji prerađuju, tumače ideje, ne istupaju frontalno, nego tumače i primenjuju ideje u rutinskim operacijama. (...) Oni nisu stvaraoci, filozofi, nego su tumači, novinari, učitelji, profesori, osoblje velikih fondacija, dakle intelektualni akteri koji omogućavaju da se ukorenjuju određene ideje u svakodnevnim interpretativnim obrascima."

Christian Promitzer, austrijski znanstvenik i sveučilišni nastavnik u članku Instrument državne vlasti ili kritičkog odmaka od nje: o regionalnoj ekspertizi austrijskih intelektualaca $u$ kasnom 20. i ranom 21. stoljeću raspravlja o očito raširenoj autopercepciji među austrijskim intelektualcima da su oni pozvaniji nego drugi na europskom zapadu tumačiti zbivanja na europskom istoku, Srednjem istoku i jugoistoku. Autor s pravom razumijeva takve autopercepcije kada je riječ o činjenici da su Beč i Republika Austrija u posljednjim desetljećima na različite načine otvoreni prema zemljama spomenutih dijelova Europe, što, obrnuto, vrijedi i za odnose zemalja o kojima je riječ s Austrijom. Dodali bismo da migracije iz svih tih zemalja prema Austriji ne prestaju, kao što ne posustaju kretati se ni austrijski građani koji $s$ različitim motivacijama odlaze u sve spomenute zemlje. Međutim, nije riječ samo o iskustvima suvremene povijesti. Habsburški dvor i Beč stoljećima su bili središta vlasti i moći za 
veći dio spomenutih dijelova europskog kontinenta te su međusobne kulturne i civilizacijske prepoznatljivosti neupitne, iako ne i uvijek kritički propitane. Međutim, za suvremene austrijske odnose sa svojim susjedstvima bitan je koncept Mitteleuropa. Njegova moderna formulacija potječe iz Prvoga svjetskog rata, dakle iz razdoblja pred slom Njemačkog Reicha i Austro-Ugarske. Neovisno o tome kako je sve i kada bio reaktualiziran, koncept je uistinu revitaliziran 1970-ih i 1980-ih godina. Učinjeno je to u mnoštvu disidentskih inačica s druge strane "željezne zavjese" na način koji je bio sastavni dio procesa demokratske transformacije srednjoistočnoeuropskih zemalja. Vrlo brzo su se u taj proces uključili brojni politički, kulturni i gospodarski akteri iz Austrije, nalazeći u reinvenciji srednje Europe jedinstvenu šansu za strateško geopolitičko, geokulturno i geoekonomsko repozicioniranje Austrije u novoj europskoj "arhitekturi". To je iziskivalo privilegiranje austrijskih motrišta u vrednovanju tranzicijskih procesa u zemljama neposrednog srednjoeuropskog susjedstva. Dakako da to nije moglo proći bez različitih klijentelističkih paternalizama. Međutim, moramo naglasiti da je aktivna austrijska srednjoistočna i jugoistočna politika u tim godinama uistinu bila legitimna i u cijelosti medijacijska. Autor je nesumnjivo u pravu kada ističe njezine ključne nedostatke, ali oni ne idu samo na adresu Austrije već neoliberalne strategije tranzicije: "Tradicija kritičke intervencije također je prisutna u Austriji, ali je ona u društvenom i političkom smislu marginalizirana. Važno je da regionalna ekspertiza u smislu kritičke intelektualne intervencije ima alternativnu predodžbu o tome što znači razumijevanje i tumačenje ili prevođenje društvenih zbivanja i događaja u istočnoj i jugoistočnoj Europi. Ta predodžba uključuje potrebu da se prevoditelj sam povuče u procesu tumačenja i da dâ glas izvornim akterima. Nasuprot tomu, proces tumačenja istih događaja u službi vlasti ima za cilj da regionalne činjenice budu interpretirane unutar neoliberalnog modela kontinentalne podjele rada i moći."

Miranda Levanat-Peričić u članku Što radi elitizam i populizam "korporacijskih" intelektualaca u Žižekovim "zanimljivim vremenima"?, koristeći Žižekovu "endističku” tipologiju ljudskih reakcija na suvremenu ekonomsku krizu - krizu koja se sve više doživljava kao "trajna" - kritički propituje publicistički i književni diskurs "korporacijskih intelektualaca" u Hrvatskoj, ograničujući se na kolumniste Jutarnjeg lista Antu Tomića i Juricu Pavičića. Javna polemika o pitanjima državnog subvencioniranja kulture i književnosti u Hrvatskoj 2012. godine pretvorila se u polemiku o kulturnoj politici u uvjetima tržišnog kapitalizma. Pritom su spomenuta dvojica kolumnista - autorski nesumnjivo vrlo prepoznatljiva u hrvatskoj kulturnoj javnosti - $\mathrm{u}$ istome dnevniku zastupala dvije oprečne kulturne politike, tj. populističku u Tomićevu slučaju i elitističku u Pavičićevu slučaju. Autorica je propitala dosege ovoga korporacijskog prakticiranja dijaloške političke kulture fokusirajući se na provjeru deklariranih načela kulturne politike u književnim štivima jednog i drugog autora. U Tomićevu slučaju bio je to roman-reklama Vegeta blues (2009.), nastao po narudžbi Podravke, a u Pavičićevu slučaju priča Brod u dvorištu (2011.).

Tomićev roman situiran je u nostalgično evocirano okružje jednog mladalačkog odrastanja 1975. godine, a "napadno istaknuti realsocijalistički okvir funkcionira isključivo kao podloga za niz reklamnih oglasa, pa se čini da su povijesne okolnosti u njemu istaknute samo zato da bi poduprle autentičnost reklamne reprezentacije". Međutim, ovaj "roman nije samo reklama nego i ideološki zagovor konzumerizma”. Na toj točki se, prema autorici, raspadaju načela Tomićeve tržišne orijentacije u kulturi jer njegov proizvod nije književno održiv, a istovremeno iznevjerava svoje konzumente. U književnom zapletu tako "trauma izo- 
staje blokirana reklamnim fabulama koje funkcioniraju kao neka vrsta simulacije stvarnosti u kojoj se uvijek nudi optimistična pobjeda dobrog proizvoda nad lošim okolnostima”.

Pavičićeva priča Brod u dvorištu, prema autorici, "paradigmatski je primjer tog 'elitnog' programa”. Fabula je relativno jednostavna: "Glavni su protagonisti priče Dinka i Srđan, sredovječni splitski par koji pred mirovinu kupuje brod i uređuje ga u dvorištu zgrade planirajući svakoga ljeta isploviti, no u tome ga pri samome kraju sprječavaju infarkt i smrt. Dinka odseljava iz zgrade svojoj kćeri u Zagreb, brod propada u dvorištu, a prilikom jednog posjeta u dvorištu susreće nesimpatične doseljenike." Kontrastirajući "fetive" Splićane s nepoželjnima Drugima u Splitu, Pavičić stvara - prema autoričinoj analizi drugih njegovih tekstova - "huntingtonovsku" sliku "Vlaja". Pritom koristi i gastronomsko-literarni instrumentarij, što pojačava učinke poruka koje smjeraju ka kulturnom ekskluzivizmu: "Osim što se hrana i leksik o hrani uvijek javljaju kao važni parametri utvrđivanja identiteta u kolonijalnom imaginariju, u Pavičićevu su tekstu ti identiteti predstavljeni kao fiksne kategorije, pa iako ne tvrdi 'svi su Vlaji isti', on uistinu tvrdi da svi Vlaji jedu istu 'pastašutu' i da je to vrlo vjerojatno oduvijek tako - možemo zamisliti da je i danas jedu kao i šezdesetih, bez 'kolonijalnih začina' za razliku od 'košer' Dalmatinaca." Zaključni autoričin stav s Pavičićem u vezi upućuje na probleme koji nipošto nisu samo "pavičićevski": "Štoviše, on sâm njeguje izrazito esencijalizirajući diskurs, inzistirajući na slici podijeljene Hrvatske, podijeljenoga grada, na slici suprotstavljenih kultura, a sukobi koji iz toga proizlaze odnose se samo na utvrđivanje gdje povući granicu i kako vrednovati podijeljeni svijet. Na drugoj su strani uvijek neki izopćenici, no vrlo bitni jer bez njih ne bi bilo ni kaste koju takav svjetonazor ustoličuje."

Nova revija je 1980-ih godina bila iznimna pojava u Sloveniji i Jugoslaviji. Ljubljanski "mesečnik za kulturo" u posttitovskom je periodu povijesti SFR Jugoslavije bio jedino glasilo koje je kontinuirano oblikovalo, pa kasnije i aktivno zastupalo antikomunističke, postsocijalističke i postjugoslavenske političke alternative u Sloveniji i Jugoslaviji. Nova revija to nikada ne bi mogla biti da nije bilo mnoštva ljudi koji su se u slovenskoj javnosti neupitno percipirali kao reprezentativan dio nacionalne kulturne elite. Ona se takvom ne bi mogla održati da ljudi koji su činili njezinu jezgru nisu bili voljni, sa svim rizicima, angažirati se na takvoj alternativnoj platformi. U članku Ivane Latković Intelektualizam tranzicije i tranzicija intelektualizma: primjer ljubljanske Nove revije moderni povijesni korijeni fenomena Nove revije traže se u tradiciji bivanja slovenskih intelektualaca na razmeđima slovenske kulture i politike. Ne podcjenjujući taj argument, nemoguće je previdjeti da je u uvjetima totalne krize jugoslavenskog društva nakon smrti Josipa Broza Tita posvuda u SFR Jugoslaviji bio otvoren proces koji je anticipirao, pored ostalog, rješenja koja će biti utemeljena na negaciji "titoističke Jugoslavije". U Sloveniji je traganje za alternativama očito najranije bilo počelo, najranije je uključilo važne dijelove službene političke i državne (republičke) nomenklature, upravljačkog sloja u slovenskom gospodarstvu ("tehnomenadžere"), ključne aktere slovenske kulture itd. Dakle, ne depersonalizirajući i ne deautonomizirajući ljude koji su činili jezgru Nove revije, činjenica je da je ona u štočemu posredno mogla biti "glasnogovornik" vrlo utjecajnih centara moći u SR Sloveniji i SFR Jugoslaviji, koji su u osnovi dijelili slične ili identične političke orijentacije. Političko i kulturno raslojavanje te jezgre nakon 1991. godine jasno je svjedočanstvo da su ključni akteri u nju ulazili i iz nje izlazili u različita vremena i na različite načine. Time iskustvo Nove revije biva povijesno važnijim. Međutim, u kontekstu globalne problematike "kraja Doba intelektualaca" slučaj Nove revije ostaje nedovoljno istraženim. Deskriptivna tipologija Petera Zajaca o četiri tipa 
intelektualaca nakon pada "komunizma" empirijski je korisna, ali ostavlja otvorenim ključni slovenski problem - status slovenske kulture u tranziciji i u Republici Sloveniji, članici Europske unije. Nisu u pitanju samo intelektualci između kulture i politike u obzorjima slovenskih povijesnih iskustava nego sadašnjost i budućnost Slovenaca kao par excellence male europske Kulturnation.

Božo Repe u svojemu članku Slovenski intelektualci danas definira problem slovenskih intelektualaca u perspektivi 20. stoljeća. Budući da su Slovenci ušli u 20. stoljeće kao narod bez bilo kakve državnosti u ustavnom poretku Austro-Ugarske i k tomu kao narod sa slabim poduzetničkim slojem, slovenski kulturni djelatnici često su bili najartikuliraniji zastupnici slovenskih nacionalnih interesa, a nisu bili rijetki ni oni među njima koji su bili i kulturni i politički djelatnici.

Paradoksalno je koliko je puta strukturalno isti obrazac odnosa politika - kultura, političari - intelektualci varirao u slovenskoj povijesti u različitim povijesnim situacijama sve do kasnih 1980-ih godina, kada je prividno iscrpljen usuglašavanjem alternativnog političkog nacionalnog programa u Novoj reviji. Građanska intelektualna elita, koja nije nestala na sistemskim marginama nakon 1945. godine, rekonstituirala se 1980-ih godina, i to, dakako, u svojim mnogoglasjima. Ona su bila prigušena samo kada se radilo o opredjeljenju da se izađe iz sistemskom krizom opterećenog jugoslavenskog socijalističkog okružja. Ne ulazeći $\mathrm{u}$ detalje u vezi s posvemašnjom nacionalnom homogenizacijom u procesu slovenskog "razdruživanja” 1990./1991. godine, Repe konstatira da je slovenska kultura nakon državnog osamostaljenja postala pluralna, i to uglavnom duž povijesno baštinjenih linija, s postupno sve jačim pomacima u desno. Naime, u državno osamostaljenje ušlo se $s$ vjerom u model "države blagostanja", koji je neoliberalna tranzicija sustavno "dekonstruirala", tako da je liberalna slovenska kulturna scena isto tako uglavnom "klizila" u desno. Komodifikacija kulturne proizvodnje također je obesmislila brojne inicijalne nacionalne kulturne prioritete iz kasnih 1980-ih godina. Institucionalno je najveći dobitnik promjena u slovenskoj kulturi bila Rimokatolička Crkva.

Izlazak iz jugoslavenskoga kulturnog prostora imao je prema Repeu uočljive negativne posljedice, ali je za slovensku kulturu dragocjeno što su brojni komunikacijski kanali u kulturi postjugoslavenskog prostora ipak očuvani, a i u samoj slovenskoj kulturi otvorene su brojne teme nužne da bi se produktivno moglo "ovladavati" prošlošću i, istovremeno, gradilo nove kulturne strategije za europsku i regionalne budućnosti.

Članak Tatjane Rosić Ugled na ponudu: intelektualci, gradani i revolucionari sigurno je jedan od onih u ovome zborniku koji bi mogli biti povod za daljnje rasprave o intelektualcima, intelektualnoj kulturi i napose o intelektualnom angažmanu u premoćno neoliberalno globaliziranom svijetu. Neovisno o mogućim suglasnostima ili nesuglasnostima s autoričinim stajalištima, pozornost posebno izazivaju njezini stavovi u vezi s intelektualcima u postjugoslavenskim državama. Sa svim predostrožnostima zbog mogućih pojednostavljivanja, njezino je temeljno stajalište moguće vrlo sažeto iskazati. Neoliberalna globalizacija put je u pogrešnom smjeru. Prema njezinu mišljenju, koje iscrpno elaborira korištenjem ključnih Bourdieuovih koncepata, formuliranje alternativa nemoguće je bez intelektualaca. Oni su, pak, sad u vrlo širokom spektru raspona marginalni "profiteri" neoliberalne globalizacije, a "u nas" i njoj imanentne postkolonijalne tranzicije. (Ne moramo prihvatiti njezinu terminologiju, ali ne možemo ne suglasiti se $s$ naglašavanjem periferijskog statusa brojnih zemalja, inače članica Europske unije ili zemalja s priznatom “europskom perspektivom”.) 
Autorica nam ipak ostaje dužna jasnije odgovoriti na pitanje kako sve brojnije intelektualne slojeve u svijetu i "u nas", a ujedno i sve više proletarizirane intelektualne slojeve na svjetskom tržištu rada društveno "reangažirati”, i to tako da budu činioci nužnih - kako sama kaže - u biti "revolucionarnih promjena”: "(...) u novim konceptima političkog angažmana ne razmatra (se) Agambenov pojam 'golog života' već mogućnosti stvaranja drugačijih društvenih i političkih stvarnosti. Sve to ukazuje na potrebu rekonstituisanja figure intelektualca-revolucionara u postjugoslovenskom kulturnom prostoru koja bi trebalo da se suoči sa budućnošću slobode i da spreči intelektualne kalkulacije sopstvenom traumom, mazohizam sticanja simboličkog kapitala, transakcije ugledom, kao i transfere iz jedne u drugu značajnu tačku društvene moći."

Način postavljanja problema u više je svojih ključnih vidova vrlo poticajan. Ograničit ćemo se na nekoliko njih o kojima se manje ili uopće ne raspravlja u drugim člancima.

Kada je o kritici suvremenog stanja riječ, suglasit ćemo se da je planetarna proizvodnja, planetarno induciranje straha, s naglaskom na egzistencijalnom strahu, jedan od ključnih instrumenata neoliberalne globalizacije ("fluidni strah" Z. Baumana, "kultura straha" H. Gigouxa, "doktrina šoka” N. Klein). Primjerice, Naomi Klein "razvija koncept 'doktrine šoka' kojim nastoji da razotkrije strategije društveno-političke paralize posredstvom koje savremeni kapitalizam ostvaruje svoju moć u zemljama Latinske Amerike i trećeg sveta, uz permanentnu pretnju upućenu siromašnima i najsiromašnijima” itd. (Još nitko nije napisao studiju o tome kako su se konstruirale i instrumentalizirale kulture straha u procesima ratnog raspada SRF Jugoslavije, kao što i danas nitko ne piše o tome kako se u postjugoslavenskim državama reciklira "strah od susjeda".)

Poticajne su i teze o intelektualnom "kašnjenju za vremenom". Primjerice, njezine ironične opaske o "novoj teorijskoj obuci" u akademskim inicijativama i institucijama (npr. rodne studije, postkolonijalne studije, feministička kritika kao samostalni kritički diskurs) - koje su došle "dve decenije prekasno" jer "rat je gotov, a i raspad i podela SFRJ završeni" - vrlo su umjesne tim više što poslije svega što se dogodilo i što se nije dogodilo domaći teorijski "univerzalisti" i danas jedino "citiraju eminentne radove iz postkolonijalnih, kulturnih i rodnih studija", ali oni i dalje ne vide u čemu je zapravo veza između tih radova i realnosti srpskog, odnosno cijeloga postjugoslavenskog prostora.

Umjesno je i njezino referiranje na temeljnu problematiku odnosa prema tragedijama i traumama ratova u kojima se raspala SFR Jugoslavija, a koji su inače potpuno nerazumljivi izvan konteksta neoliberalne globalizacije. Otvarajući pitanje "ovladavanja prošlošću" u ime budućnosti, autorica je u ovaj zbornik legitimno uvela Damira Arsenijevića, "teoretičara nove generacije" koji se zalaže za "prevazilaženje traumatske investicije" u cilju stjecanja simboličkog kapitala, jer je to uvijek "investicija u prošlost, vođena nekrofilnom politikom koju su uspostavili kolonizatori, a ne žrtve”.

Još nešto na temu intelektualnog "kašnjenja za vremenom" u svijetu ili "u nas". Nemoguće je previdjeti da u svijetu između 1968. i 1989. godine u krizi nije bio samo intelektualni angažman u stilu jednog Jean-Paul Sartrea. Svjetonazorno intelektualci nikada nisu bili samo ljudi vrijednosnih orijentacija od lijevih liberalnih do radikalno lijevih. Prije svega, intelektualci su u 20. stoljeću bili protagonisti i akteri svih vrijednosnih orijentacija s "desna" na "lijevo", a staljinizacija Ruske revolucije već je 1920-ih godina do krajnosti zaoštrila pitanje što uopće jest, a što nije "lijevo" ili "desno". U međuvremenu su stvari postale mnogo složenijima, pa je kraj "Doba intelektualaca" bilo moguće predvidjeti. Iako su danas izazovi globalni, jedino što je nemoguće globalizirati je "svjetska revolucija”. Neupitno 
je da globalizacija svijet istovremeno čini i sve neravnopravnijim, različitijim itd. Uvjereni smo da su humanistički utemeljene alternative moguće, ali ne vjerujemo u njihove "instantprodukcije" i "instant-efekte".

Pišući o tumačenjima i prikazivanjima intelektualca-umjetnika danas u hrvatskoj, slovenskoj i srpskoj književnosti, Zvonko Kovač u svojemu članku Tumačenje i prikazivanje intelektualca-umjetnika danas ne ograničava se samo na radove suvremenih književnika nego i na suvremene recepcije ključnih djela moderne književnosti u perspektivi 20. stoljeća. Riječ je prije svega o djelima koje je moguće čitati na postmoderan način. Takvim pristupom naši su suvremenici i Ivan Cankar kao i Marjan Rožanc, Miroslav Krleža kao i Boris Perić te Oskar Davičo kao i Vladan Desnica, o kome se u ovome zborniku posebno govori. Njih ne povezuju samo iskustva "Doba intelektualaca". Upravo obrnuto. Iz postmodernističke kritike njegove baštine oni kao književnici, odnosno njihova djela, dobivaju svoj novi smisao.

Ivan Cankar jedan je od takvih u Hrvatskoj zaboravljenih pisaca koji ponovno postaje i u nas aktualan nakon što ga je nedavno, stotinjak godina poslije smrti, otkrila austrijska kultura. Njegov roman Tujci (1901.) intelektualni je roman o intelektualcu kao strancu, a Kovač će dodati i o drugome, kako u vlastitoj kulturi tako i u tuđini. Riječ je, dakako, o intelektualcu, umjetniku, poniklu u malom narodu, stvaraocu univerzalnih obzora kojemu je vlastita kultura preuska, ali koji je istovremeno predodređen biti stranac i u kulturnim prostorima velikih naroda. S hrvatske strane Milan Marjanović vrlo je brzo nakon objavljivanja Cankareva romana u zagrebačkom Obzoru o njemu pisao s entuzijazmom kao o djelu koje postavlja ključna pitanja intelektualne kulture "malih naroda" u svom vremenu i istovremeno na njih odgovara: “(...): trebamo spoznati svoju malešnost i odbaciti poniznost, jer malen će narod prevladati i nadoknaditi 'pomanjkanje mnogobrojnosti svojih članova i tjesnoću svoje kuće' samo s intenzivnosti života, razvijanjem napetosti življenja, individualiziranjem društva. Kao što je to uspjelo sjevernim malim europskim narodima.” Apostrofirajući individualni voljni aspekt napora izlaska iz "tjesnoće svoje kuće”, Marjanović, slijedeći na ovome mjestu Cankara, postulira skandinavski, nordijski model građanskog oslobođenja, dakle svojevrsnu utopiju. Utopijska "skandinavizacija Balkana" ostat će cijelo stoljeće mitski orijentir "intelektualnih elita" malih naroda europskog jugoistoka, dalekih i od vlastita naroda i od Skandinavije kao kulturnog realiteta. Ne ulazeći u to koliko je "skandinavska formula" mogla biti važna i za samog Cankara, itekako ima smisla suočiti se $s$ pitanjem kako su se sve i kada južnoslavenske intelektualne elite u 20. stoljeću uspijevale repozicionirati s marginalnih statusa u vlastitim društvima na centralne, u kojim situacijama i s kojim ograničenjima. Cankar je s mnogim oklijevanjima takvu mogućnost bio otvorio.

Povratak Filipa Latinovicza Miroslava Krleže i Povratak Filipa Latinovića Borisa Perića, objavljeni u Zagrebu 1932. i 2013. godine, koliko god literarno korespondirali, dva su oprečna pristupa tujstvu intelektualaca: "Tako se zarana spuštamo u hrvatsku tranzicijsku zbilju, kojoj je središte zapravo gornjogradska krčma Pod mirnim krovovima i alternativno prostori sado-mazo studija, koji vodi psihoterapeutkinja gospođa Ksenija Radović (Raday), a u kojemu pojedinci tjelesnim tretmanom istiskuju demona žudnje iz svoje 'poremećene' psihe. Filipova samopotraga, njegov pokušaj povratka među zdrave i uspješne umjetnike, preko rasprava koje vode u evidentno kriminalnome miljeu, kao da bjelodano pokazuju razliku između Krležina Povratka Filipa Latinovicza kao europskog, svjetskog romana i Perićeva istoimena djela kao pravog romana domaće književnosti, upravo iz sredine, pri- 
sjetimo se Marjanovića, koja nije spoznala svoju malešnost i odbacila poniznost, odnosno koja nije išla prema intenzivnosti života, razvijanjem njegove 'napetosti' i 'individualiziranjem društva."

Ivan Galeb Vladana Desnice u romanu Proljeća Ivana Galeba (1957.) retrospektivno meditira u bolesničkoj sobi o svom životu intelektualca, reproduktivnog umjetnika, koji se klonio kako javnih tako i privatnih, intimnih izazova. Razapet između života i smrti, Ivan Galeb teži mirenju sa životom: "Njegova pomirenost sa životom ne proizlazi iz osjećaja ispunjenja svoje profesionalne ili životne situacije, nego baš obratno - iz spoznaje o relativnosti vrijednosti, slučajnosti uspjeha i skrajnutosti intelektualca-umjetnika od svih zbivanja u društvu. Ne kao romantičnih donkihota, neshvaćenih pjesnika, već više kao postmodernističkih intelektualaca koji zapravo nisu potrebni jer ih 'imanencija postmodernističke paradigme eliminira i čini nepotrebnim', pretvarajući ih ili u slabe neautentične subjekte ili u zagovornike loše politike." Suglasili bismo se sa Zvonkom Kovačem da je Ivanov zakašnjeli dijalog sa "slavnim glumcem" jedan od ključnih Desničinih romanesknih doprinosa raspravi na temu o intelektualcu danas. Mnogo toga što umjetnika motivira u stvaralaštvu svodi se na banalne motive. "Nakon smrti boga", kaže Kovač - slijedeći Desnicu - "nastale su razne metafizičke koncepcije umjetnosti, koje su trebale pomoći osmišljavanju života, umjetnost je postala gotovo 'tajanstveno nadnaravno otkrivenje', čemu pridonose najsuvremenije teorije podsvijesti, iracionalnog i intuicije. Bijeg od umjetnosti, ostajući još uvijek u njezinim granicama, s iluzijom da se odustajući od primarnoga poziva uspinjemo za stupanj više, krajnja je samoobmana (...) I ne na kraju, kako u zanosnom sabiranju glumca razumijemo, u umjetnosti preživljava tek velik umjetnik, osobnost koja u sebi 'udružuje velik um, velik duh i velik talent', koji nadrasta sam sebe, svoju umjetnost i umjetnika u sebi." Dakle, sve što Desnica ima reći stalno je variranje misli o umjetnosti i “čovjekovom očovječenju”. Problem umjetnika, intelektualca kao stranca, time se sasvim drugačije postavlja.

Bojan Đorđević binarno formuliranim podnaslovom članka Intelektualac kao književni lik: od heroizma do kiča doista intrigira čitatelja. Polazi od tvrdnje o postojanju analogije između intelektualnih odgovora na univerzalna pitanja i probleme "u realnom prostoru i vremenu" u modernoj epohi, tj. u 19. i 20. stoljeću, i "načina percipiranja" istih tih intelektualnih pitanja i problema "u vremenu i prostoru naracije". Stoga su prozna djela tog doba bila prije svega oblikovana kao "intelektualizovano pripovedanje": "To je uticalo na to da", $s$ jedne strane, "više nego bilo koji drugi književni lik, upravo lik intelektualca suštinski bude ideološki uslovljen", a s druge je strane "ideologizacija (...) nalagala da i književni likovi vrše društvenu funkciju različitu od funkcije drugih sistema”. Time je uvijek postojala "opasnost da kada se ti drugi sistemi - pre svega filozofski, etički i politički - ospolje kroz totalitarni diskurs, (...) i književni lik intelektualca postane 'ideja koja govori'”. Autor usvaja i aporičnu tvrdnju o prozi 19. i 20. stoljeća - naročito romanu - kao o "narativnom suočavanju s istorijom" - referirajući se na naratora Rata i mira, "predmet istorije je život naroda i čovečanstva”. Do Prvoga svjetskog rata, Đorđevićevo je mišljenje, književnici "postvaruju 'ideju nacije", a tek poslije njega "događa se u srpskoj i hrvatskoj književnosti 'agon sa istorijom"': "Istorija biva prvi put negativno valorizovana (Krleža, Cesarec, Crnjanski, Vasiljev). Intelektualno suočavanje sa istorijom predstavljalo je u tim delima (na fonu ekspresionizma) zapravo određenje prema njenom ekstremnom pojavnom obliku - ratu." Autor sugestivno i konkretizira ovaj svoj stav: “(...) književni lik intelektualca u prozi do Prvog svetskog rata imao je zadatak da verbalizuje (i afirmiše) realnu strukturu sveta koja 
prethodi jezičkoj delatnosti (tj. književnom delu). Posle Prvog svetskog rata, književni lik intelektualca iz fiktivnog vremena naracije projektuje duh koji nastoji da preosmisli realnost. I tu u suštini i leži glavna napetost - u tom neskladu sposobnosti i namere književnog lika intelektualca i njegove delatnosti. Čitav Krležin roman Na rubu pameti i jeste utemeljen na tom neskladu koji postaje tragička krivica glavnoga junaka." Đorđević vrlo jasno formulira problem "kraja Doba intelektualaca", slijedeći mainstream shvaćanje u svijetu: “(...) nastojanje intelektualaca da se postvare kao kritički nadmoćni glasovi savesti, a uz to njihovo prečesto koketiranje sa upravo etički upitnim ideološkim i socijalnim, a napose političkim nazorima i praksom, izazvali su reakciju. $\mathrm{Na}$ delu je, zapravo, u poslednje dve decenije dekanonizacija, (...) izgubio se i književni lik intelektualca kao rezonera, pobunjenika ili grešnika - a to znači da više nema herojske ili tragične figure intelektualca." Ovdje bismo mogli reći - imajući na umu kasniji razvitak "intelektualizovanog pripovedanja" u modernoj hrvatskoj i srpskoj književnosti, primjerice romane M. Krleže Povratak Filipa Latinovicza (1932.) ili V. Desnice Proljeća Ivana Galeba (1957.) - anticipacije nekih ključnih postmodernih izazova bile su i "u nas" literarno formulirane daleko prije postmoderne. Da zaključimo. Moderna intelektualna kultura "u nas" i u svijetu, a napose intelektualne prakse moderne epohe iziskuju "bespoštednu kritiku". To je i zadatak jedne nove intelektualne historije i, distinktivno, povijesti intelektualaca. U prihvaćanju tog izazova književnost nerijetko prednjači historijskoj znanosti, kao i toliko puta u posljednja dva stoljeća. O tome svjedoči i ovaj članak.

Dominantni trend u suvremenoj književnosti autor je uistinu jasno elaborirao: “(...) u poslednjim decenijama (od osamdesetih godina dvadesetog stoleća do danas), u tzv. savremenoj prozi književni lik intelektualca doživeo je transformaciju, i više se ne može umetnički zrelo i dosledno ospoljiti kao heroj ili grešnik, tj. kao posednik određenih etičkih imperativa. Pre svega zbog odnosa prema istoriji, koji je bitno odredio - a određuje i dalje - dominantne tokove hrvatske i srpske proze. Stoga su i likovi intelektualaca u tzv. postmodernoj prozi, pa i docnije, uglavnom izloženi parodiji ili destrukciji. To je nužna posledica reakcije na dehijerarhizaciju i nivelaciju semantičkih i vrednosnih polja u samom realnom diskursu. Drugi razlog je obilje informacija koje oduzima mogućnost književnom liku intelektualca da nastupa sa superiorne tačke gledišta. Kao što je još Lyotard primetio, nema više ni velikih priča ni velikih heroja." U srpskoj i hrvatskoj književnosti koliko god bilo stvaralaca koji su upravo u tom smislu prepoznatljivi, ništa manje nije uočljiv i obrnut trend: “(...) insistiranje hrvatskih i srpskih prozaista, koji pokušavaju da u svojim delima verifikuju vanknjiževne mitologeme, na hijerarhijskom poimanju stvari, na prevalentno intelektualizovanom vrednovanju kroz govor i delanje intelektualca kao književnog lika, dovodi do toga da takav lik postaje obična 'ideja koja govori', tj. kanonizovana kič-figura bez dubljeg utemeljenja u fikcionalnom svetu u kome obitava".

Međutim, kakvi god bili i što god zasluživali, intelektualci nikada nisu imali monopol na "glas savesti", a legitimiranje "etički upitnih ideoloških i socijalnih, a napose političkih nazora i praksi" češće je konkretnohistorijski bila "zasluga" "elita moći”, birokratskih i vojno-policijskih sistema, poduzetničkih klasa ili "pobunjenih masa" nego intelektualaca, koje, dakako, nikako ne treba abolirati od "bespoštedne kritike". ${ }^{5}$ U vrijeme kada je bu-

Ključni je problem postmodernog "obrata" koncem 20. i početkom 21. stoljeća što je delegitimirao imperativ kritičkog propitivanja iskustva (još jedan obesmišljeni pojam!) moderne epohe, 19. i 20. stoljeća, u kojima ljudska vrsta istovremeno i najviše "humanizira" i najviše "dehumanizira" ono što se u dugome europskom trajanju zove conditio 
dućnost svijeta sve neizvjesnija, a prošlost sve zatamnjenija, literarna "dekonstrukcija" "lika intelektualca", koliko god bila imperativno potrebna, očito ima i svoju nepropitanu stranu. ${ }^{6}$

Zoltán Virág u članku Waterworlds: Allusions and Illusions (Tropes of River, Delta and Sea in the Poetry and Prose of Uj Symposion Literary Magazine) propituje "geopoetiku" književnika koji su u mađarsku i južnoslavenske kulture ušli kao suradnici novosadskoga časopisa na mađarskom jeziku Új Symposion (1965. - 1971.). Među njima je ključno stvaralačko ime bio Ottó Tolnai. Časopis je počeo kao neoavangardno glasilo, jedinstveno po svojim kreativnim učincima i u Mađarskoj i u Jugoslaviji. Kasnije je evoluirao u smjeru konceptualne umjetnosti. Administrativno je zabranjen koncem 1971. godine kao jedno od politički suspektnih glasila u vrijeme kontrarevolucionarnih paranoja. Virágov je esej pokušaj da se poetika suradnika časopisa interpretira kroz pjesničke aproprijacije geokulturnog prostora koji integrira Panonsko "more" s Jadranskim morem, sa Sredozemljem, te panonske rijeke i njihove delte $s$ jadranskima. Pjesnički transformirajući pejzaže, oni osporavaju logike isključivosti i kulturnih predrasuda. Za pjesnike kao što su Ottó Tolnai, István Domonkos, Katalin Ladik, László Végel, Ferenc Maurits, Pál Böndör, Attila Balázs i Ottó Fenyvesi pitanja identiteta, koliko god zavičajna, toliko su i nerazlučiva od čovjekova kretanja i seoba, pri čemu se čovjek realizira do granica svojih mogućnosti (the makró, the guerilla, the joculator, the strolling musician, the Yugo-Sindbad, the artist as hooligan and the rocker). Individualnim aproprijacijama različitih regionalnih kulturnih identiteta nastaju kompleksne artističke sklonosti i potrebe, kao jedna od temeljnih pretpostavki poetskog dijaloga.

Mile Stojić nedavno je zapisao i vrijedi to ovdje ponoviti: "Ottó Tolnai je, moglo bi se reći bio predvodnik i duhovni lider te značajne generacije autora, među kojima su se još isticali István Koncz, pjesnik, Nándor Gion, prozni pisac, Tibor Váradi, prozaist, István Domonkos, pjesnik i romansijer, István Brasnyó, pjesnik i prozaist, László Végel, prozaist, dramski pisac, romansijer i esejist, László Gerold, kazališni kritičar, Csaba Utasi, književni kritičar, István Bosnyák, književni povjesničar i publicist, Kálmán Fehér, pjesnik, Katalin Ladik, pjesnikinja i glumica, Ferenc Deák, pjesnik, dramski pisac i scenarist. Ta generacija, rekli smo, bila je za generacije mladih pisaca širom Jugoslavije svojevrstan kružok avangardnih stremljenja, otimali smo se za prijevode njihovih pjesama i eseja objavljivanih tih godina po srpskoj i hrvatskoj književnoj periodici."7 Čitajući Stojićev esej o Tolnaiju, nemoguće je bilo previdjeti fragment o njegovu panonskom odnosu prema moru: "Na novinarsko pitanje kakva je razlika između jugoslavenskih i mađarskih Mađara, Tolnai je u jednom davnom novinskom intervjuu odgovorio: razlika je u tome što jugoslavenski imaju more. Može zvučati paradoksalno, ali Tolnai je jedan od najvećih pjesnika i zaljubljenika mora. Uvodna pjesma - molitva govori o nihilizmu koji je produkt velike beskrajne patnje: 'nemoj me spasiti/ znam nisi nikada nikog ni spasio/ ali bojim se da ćeš sa mnom učiniti iznimku'.” Virágov je esej mogući putokaz za rekonstrukciju jedne poetske pozicije i jedne

humana. Paradoksalno je da se u vrijeme kada se svijet iz dana u dan sve više globalizira, istovremeno sve više delegitimiraju načela univerzalizma u svjetskoj zajednici ljudi.

6 Nedavno smo mogli u novinama čitati o projektima medicinski kontroliranog ugrađivanja digitalnih čipova novorođenčadi, a 12. srpnja 2014. mogli smo u zagrebačkom Jutarnjem listu pročitati članak "Ovo je pametni metak: gađa metu bez ciljanja". Članak je nadnaslovljen "Municija 21. stoljeća. SAD testirao novo oružje”, a podnaslovljen "Meci imaju ugrađeni čip koji omogućava navođenje na udaljenost od dva kilometra". Čovjek ne može ne zapitati se kako to da gromoglasnu dijabolizaciju totalitarizama prošlosti danas prati jedva čujna anticipacija nadolazećih totalitarizama budućnosti.

7 Mile SToJı́́, "Pjesnik erudicije i tjeskobe" (http://82.149.22.226/ mobcinamb/index.php?ptype=8\&menu=0\&id=2 20\&Pid=826\&echosub=1). 
geopoetike koja u Europi bez granica neće morati biti stvar jednoga antikvarnog iskustva. Naprotiv, mogla bi biti poziv za jedan novi pjesnički početak.

Ivan Radenković u članku Neoliberalni i eurokomunistički intelektualac polazi od pretpostavke, kada je o eurokomunizmu riječ, da "bavljenje intelektualnim avanturama pokreta koji u društveno-istorijskom smislu predstavljaju neuspeh može izgledati kao izraz nemoći da se pruže realne alternative za aktuelno društveno stanje. A opet, izgleda da nam istorija socijalističkog neuspeha govori podjednako kao i neoliberalna racionalnost o tome šta ne treba činiti sa društvom." Koliko god strategija eurokomunizma post factum bila ahistorijska, neoliberalne strategije "pate" u biti od iste "boli" jer "[n]eoliberalni set mera sadrži transistorijsku dimenziju jer ne uzima u obzir specifičnosti društava kojima je namenjen, njihove istorijsko-materijalne uslove, te na taj način nastupa sub specie aeternatis". Radenković je mišljenja da i neoliberalni intelektualci sa svojim subjektivističkim utilitarizmom te metodološkim individualizmom također doprinose neoliberalnom transhistorizmu, čineći od njega paradoksalnu nedruštvenu teoriju društva. Za razliku od klasičnog liberalizma, neoliberalizam je obrnuo odnos između političkog i ekonomskog. John Maynard Keynes i lord Beveridge su kao liberali stvarali “državu blagostanja”. Stoga ih je neoliberal Hayek izravno dovodio u vezu sa sljedbenicima kolektivističkih političkih ideologija. Ipak su socijalistički intelektualci bili u središtu kritike, npr. "socijalistički intelektualci su selektivni, oni biraju samo one ideje koje su drage državi, dok neoliberalni intelektualci, kao prave demokrate, učestvuju u razmeni svih ideja”. Neoliberalni intelektualci, fokusirajući svoj interes na promet roba, nisu imali interesa za analizu odnosa proizvodnje. Njima je bilo važnije opravdati kategorije važeće raspodjele ukupnog društvenog dohotka. Društvene su odnose time preusmjeravali iz sfere proizvodnje u sferu razmjene: "Klasična radna teorija vrednosti zamenjena je mikroekonomskom teorijom koja odvaja politiku od ekonomije, a istorijske forme zamenjuje logičkim formama." Intelektualna kultura neoliberalizma čvrsto je ukorijenjena u pretpostavci da su "svi ljudi (...) (barem in potentia) kapitalisti, jer je to prirođeno čoveku kao takvom. Biti kapitalista (preduzetnik, lovac na profit...) se stoga ne misli kao istorijska, nego kao transistorijska odredba."

Eurokomunistički koncept, nastao u realnostima "države blagostanja”, napustio je marksistički linearizam prijelaznih faza između kapitalizma i komunizma, kao društva bez klasa. Njegovim je akterima ključno bilo definirati prijelazno razdoblje kao doba antimonopolističkih saveza, koji će otvoriti nove puteve $\mathrm{k}$ socijalističkom prijelaznom razdoblju. Htjelo se to postići političkim prilagođavanjima, a posebno "odvajanjem društvene od političke borbe" te "nacionalnim putevima u socijalizam" itd.: "To je podrazumevalo stvaranje strategije klasnih saveza čiji su efekti doveli do rascepa između političke akcije kao partijske stvari i šire društvene akcije kao sindikalnog zadatka." Međutim, ključno je bilo eurokominističko prihvaćanje iluzija da je "[f]ordistička politika relativno visokih najamnina delovala (...) kao kompenzatorni mehanizam koji je trebao pomeriti i zamagliti konfliktno polje rada i kapitala na razini proizvodnje, premeštajući tako radničku klasu u sferu potrošnje - ovaj fenomen je ono što se naziva istorijskim klasnim kompromisom. Ovi procesi su doprineli stvaranju iluzije kod eurokomunističkih intelektualaca, iluzije koja je računala na spremnost kapitalizma za mirni prelazak u društvo napredne demokratije.” Eurokomunistička ahistoričnost otvorila je time širom vrata neoliberalnoj ahistoričnosti.

Za razliku od, primjerice, Vjerana Zuppe i Alpára Losoncza, Vladimir Gvozden u svojemu članku Intelektualno pisanje i otpor historizira - referirajući na Christophea Charlesa - fenomen intelektualaca u francuskom društvu nakon cca. 1880. godine. Riječ je bila o 
eliti obrazovanih kojoj su mediji bili otvoreni i koja je htjela steći "simboličku moć" potrebnu za nadmetanje s drugim elitama u kontroli ekonomske i političke moći u francuskom društvu. Bili su to ljudi koji su brojniji nego ikada izlazili iz vrhunskih francuskih obrazovnih ustanova, ustanova s međunarodnim prestižem. Mogli bi se u ponečem uspoređivati s prosvjetiteljskim literatima 18 . stoljeća ili savantsima 19 . stoljeća, ali su oni sociokulturno, pa i statusno bili nov fenomen u francuskoj povijesti i takvima su ostali sve do druge polovice 20. stoljeća, dakako ne previđajući velike promjene i u francuskom društvu u sekularnom rasponu, kao i u (auto)percepciji intelektualaca. (Moderni intelektualni fenomen u isto to doba, možda i ranije u nekim slučajevima, poznaju i druge europske, pa i izvaneuropske zemlje.)

Za autora je intelektualac "dispozicija" koja je ostvarena djelovanjem različitih uočljivih ili manje uočljivih društvenih, političkih i kulturnih "vektora", "a ne nekakvo stabilno i zajamčeno mesto u periodnom sistemu elemenata”. Jesu li intelektualci prvenstveno dubinski produkt procesa demokratizacije društva ili je njihovo porijeklo u istoj toj povijesnoj situaciji kompleksnije, važno je pitanje s višestrukim implikacijama. Međutim, neupitno je da je "povlašćenost njenog postojanja sve više iščezavala, pothranjivana plemenitim verovanjem da svaki subjekt može da postane stvaralac, a svaki predmet lep. (...) Tako se on (intelektualac - nap. ur.) obreo u aporiji, gubio je povlašćeno mesto unutar lanca tumača društvene stvarnosti u ime političkog koncepta koji nije mogao da ospori, jer je upravo taj koncept bio glavni uslov modernih, a pogotovo kritičkih avangardnih i modernističkih intelektualnih praksi." U suvremenoj perspektivi, "u doba dominacije vizuelnog, reč je upala u vrtlog ubrzanja. Trajanje potrebno kako za njeno konzumiranje, tako i za vrednovanje, dramatizovano je kroz novu ekonomiju vremena, kroz instance video slika i fluktuacije neona." Potonje su već bili samo neki simptomi dubokih promjena i u društvu i među intelektualcima koncem 20. stoljeća: "Neizvesnost omogućuje da bilo šta dobije na značaju, a budućnost izgleda kao sadašnjost sa više opcija. (...) Korak po korak, sumorne političke činjenice dovode u pitanje naš estetizam okrenut svetu roba, ali i tradicionalno zamišljene kulture. (...) Naše protivrečno doba je istovremeno obeleženo kulturnom hegemonijom i beskonačnim umnožavanjem identiteta, kultura i vrednosti." Ključno je da se u doba demokratizacije "svega" "glas intelektualca pretvara u jedan mogući glas u mnoštvu glasova". Težište je na mnoštvu glasova, na "usamljenoj gomili" ili, nasuprot tomu, na interesnim skupinama: "Današnja država ne vodi računa o individualnim učesnicima određenih društvenih situacija, već se bavi klasifikacijama: nezaposleni, maloletnici, lobiji, ranije osuđivani, biračko telo, regioni, nevladine organizacije, ciljne grupe, etničke grupe... I intelektualni rad se u velikoj meri uklopio u koncepte države znanja i ideoloških predstava, ali i marketinških ciljnih grupa: etno literatura, šik literatura, epska fantastika, romani o zaverama, popularna psihologija, ilustrovana istorija, uputstva za samolečenje, Hegel za početnike i slično.” Bitno je uočiti da se alternativni pokreti savršeno uklapaju u ovu segmentnu shemu: "Alternativni pokreti, uključujući i one umetničke, tragaju za partikularnim identitetom, a ne za univerzalnošću. Krajnji stadijum modernog individualizma nije nedruštveni, otuđeni subjekat, već su to minijaturni mikrokolektivi posvećeni specijalizovanim interesima.” Kada je o intelektualnim kulturama riječ, prevladava mišljenje da "ovom procesu ključni doprinos daje iščezavanje utopija, oličeno u nestajanju verovanja da će svet sutra biti bolji, odnosno u širenju neverice u bilo kakvu stalnost kao kategoriju savremenosti, kako u ekonomskom, tako i u širem kulturološkom smislu”. Ako je riječ o "intelektualcu danas", ključno je pitanje mjesta intelektualca nakon kraja utopije. Autorov je odgovor ambivalentan: "Odmah se, bez 
mnogo spekulacije, može reći da je to mesto paradoksalno, jer kritičko mišljenje, $s$ jedne strane, zadržava mnoge tradicionalne elemente i uklapa se u savremeni ideal pluralizma i šarolikosti, dok, s druge, biva potisnuto na marginu kao diskurs vredan pažnje, pogotovo kad je reč o njenom pravu na složenost u poetičkom, ideološkom, etičkom smislu. (...) 'Pogledaj nas kako uživamo', to je glavni poklič sadašnjice, oličen u vizuelnom egzibionizmu društvenih mreža i novih medija. Njega je pripremio takozvani moral autentičnosti čiji se kategorički imperativ sastoji od dve reči: be yourself." Pitanje otpora takvu stanju nije ni jednoznačno, a ni jednostavno. Ohrabrujućih mišljenja ipak ima: "Prema poznatom razmišljanju Foucaulta, otpora ima tamo gde ima moći; otpor nikada ne leži izvan moći. (...) Foucault ne razume moć kao poredak građanske države, već kao 'mnogostrukost odnosa snaga koje organizuju jednu teritoriju'. Za Foucaulta, moć nije nešto što neko poseduje, već štaviše, nešto što se razvija, ne toliko stečena privilegija vladajuće klase, već štaviše skupno dejstvo njenih strategijskih pozicija. (...) Da li intelektualno pisanje može da pomogne u strategijskom kodiranju tačaka otpora? Možemo li govoriti o moći otpora umesto o otporu moći? Možemo li prozboriti o anti-moći? Danas se gušimo u shvatanju da je moć svuda i istovremeno nigde. Ima li intelektualno pisanje dovoljno mašte da makar stvori uverljivu fikciju o tome kako da opozicija od reaktivne postane ofanzivna, u samoj sebi zasnovana figura? Kako ocrtati linije topične utopije?” Sve su to pitanja koja definiraju istraživačku agendu i koja otvaraju nadu.

Filip i Nikolina Šimetin Šegvić, zagrebački doktorandi na studiju povijesti, kao autori članka Intelektualac pred ogledalom: rasprava o intelektualcima danas i voditelji internetskog intervjua s nekoliko uglednih intelektualaca s raznih strana svijeta (Pierpaolo Antonello, Carol Becker, Dietz Bering, Carlo Bernardini, Hauke Brunkhorst, Chester Finn Jr., Steve Fuller, Henry A. Giroux, Nathan Glazer, Gerhard Ruiss, Boris Vezjak i Simon Sheikh) o pitanjima koja su bila predmet rasprave na Desničinim susretima 2013., unose i načinom razmišljanja i formama prezentacije prepoznatljive generacijske novine u raspravu o "intelektualcima danas". Nije ovdje riječ o tome jesu li očito talentirani mladi autori manje ili više pametniji od generacije svojih roditelja, manje ili više obaviješteni, manje ili više otvoreni prema suvremenome svijetu. Riječ je o tome što formuliraju kao problem i kako o otvorenom problemu razmišljaju. Kontrastirajući na nekonvencionalan način televizijsko iskustvo A. J. P. Taylora na BBC-jevu Challangeu 1957. godine i iskustvo Reze Aslana na američkom Foxu 2013. godine, autori su postavili mnoštvo intrigantnih pitanja o "intelektualcu danas", k tomu prelomljenih kroz medijsku, televizijsku optiku. Pitanje je koja bismo sve pitanja mogli postaviti da je u drugome slučaju bio izabran primjer intrigantnoga medijskog izazova upućena s Foxa kakvu američkom profesoru s Harvarda ili University of Chicago, "bijelog" (isprika zbog političke nekorektnosti!) i, recimo, protestanta itd.

Međutim, prihvaćajući ponuđeni pristup, ne možemo ne suglasiti se s autorima da su se vremena stubokom promijenila, i to upravo u smjeru koji ovaj članak argumentirano elaborira. Kritički intelektualac danas, ako uopće ima interesa pojaviti se kao intelektualno prepoznatljiva osobnost u nekoj televizijskoj emisiji, mora na bezbroj načina pokušati unaprijed zajamčiti pravo na zaštitu svoje autentičnosti na ekranu jer zna da na bezbroj načina može biti izigran, zloupotrijebljen, u konačnici - obesmišljen, ponižen, i kao intelektualac i kao čovjek. Najčešće uopće ne mora brinuti te brige jer mu se neće niti pružiti prilika da išta suvislo kaže o bilo čemu o čemu bi mogao biti pozvan medijski se očitovati. Dakle, slijedeći ponuđene probleme i pristupe, bitno je zapitati se koliko se uopće neoliberalni komunikacijski sustavi žele baviti temama i pristupima koji neoliberalni poredak - poredak 
"kraja povijesti" - konsekventno pokušavaju dovesti u pitanje. Odgovor je vrlo jednostavan pa jedino što ostaje i kritičkim intelektualcima i medijskim korporacijama - bar u demokratskim porecima - različite su strategije ograničenog približavanja. Kritički intelektualci pritom obično lošije prolaze.

Internet je u svakom slučaju civilizacijski poželjna novina, dalekosežnih kreativnih potencijala, ali sve što smo u posljednje vrijeme saznali zahvaljujući Assangeu i WikiLeaksu, Snowdenu i svima onima koji stoje iza, ispred ili pored njih, duboko je zabrinjavajuće i seže u same epicentre onoga što se kumulativno iskazuje izrazom "budućnost ljudskoga roda". Nije li to još jedan zadatak za kritički misleće intelektualce?

Problem je tim veći što je velik dio intelektualne kulture 20. stoljeća nastao u obzorju projicirane ili realizirane "države blagostanja", ali i njezinih alternativa. Veliki dio te kulture nezamisliv je bez implicitnog ljudskog prava na utopiju, na imaginaciju, na humanistički definirane potrebe, nadu itd., itd. Ne ulazeći u daljnju elaboraciju u tom smislu, bitno je naglasiti da sva ljudska zla 20. stoljeća teško mogu danas biti kritički propitana ako ne budu propitane i njima suvremene alternative. To se ne može napraviti ako se generalno delegitimira baštinjena intelektualna kulturu i proglasi neoliberalni "novi svjetski poredak" kao mjerilo svih stvari danas, ali i jučer i sutra. Nije li u tome glavni problem "intelektualca danas"?

Desnicu - kao i svakog velikog pisca - moguće je danas čitati kao modernista, ali i kao antimodernista, a nerijetko i kao postmodernista. $\mathrm{O}$ tome se $\mathrm{u}$ ovome zborniku iscrpnije govori u članku Drage Roksandića Vladan Desnica, intelektualac danas. Kako god "dekodirali” Desnicu, nijedan zaključak ne može proći bez nekog novog pitanja imanentnog njegovoj kulturi mišljenja. Treba čuti što o "intelektualcu danas" kažu njegova "lica" u Proljećima Ivana Galeba, svojevrsnoj sintezi njegova stvaralaštva. ${ }^{8}$ Klasični modernist Vladan Desnica misli da je "[v]iše-manje svako (...) veliko književno djelo, na ovaj ili onaj način, jedan slučaj savjesti, a književna aktivnost u stvari i nije drugo nego jedan neprestani ispit savjesti". ${ }^{9}$ Problem je naglašenije etički nego estetički. Na istom mjestu dodaje da je vrijednost književnog djela "baš u tome što tek takva, psihološko-lirska vrsta ispita savjesti, a ne puka intelektualistička, etička, sociološka i tako dalje, ujeda, i razbuđuje, i promiče nešto u najintimnijoj intimnosti čovjeka". ${ }^{10}$ Koliko god ono moglo biti prodornije u takvu (samo)ispitivanju, za Desnicu "postmodernista" sporna je prije svega sama umjetnost: "U umjetnosti, naime, postoje dva oprečna, antinomična momenta, a oba podjednako osnovna za umjetnost; momenat spontanosti, izvornosti, naivnosti - dakle momenat liričnosti, - i momenat umještine, nekog 'činjenja', 'izvještačivanja', ukratko momenat artificijuma (...) I eto, između ta dva pola, u rasponu tih dviju oprečnosti, liričnosti i artificijuma, umjetnosti svojstvene istine i laži, protječe čitav život umjetnosti i leži njen vječiti dijalektički momenat". ${ }^{11}$ Nasuprot svim mogućim propitivanjima granica umjetnosti u vezi s njezinim "vječitim dijalektičkim momentom", Desnica, uvjetno rečeno "antimodernist", svjestan je i njezina epohalnog ograničenja: "Veliki umjetnici današnjice još su uvijek grobari jednog dotrajalog reda stvari, jednog svijeta na umoru, ne nosioci pozitivne afirmacije, objavitelji jednog novog životnog principa. Najznačajnija umjetnička ostvarenja današnjice imaju

Vladan Desnica, Proljeća Ivana Galeba, Zagreb 1975.

Isto, 224 .

10 Vladan Desnica, Hotimično iskustvo: diskurzivna proza Vladana Desnice, knjiga druga, prir. Dušan Marinković, Zagreb 2006., 79.

11 V. Desnica, Proljeća Ivana Galeba, 215-216. 
uglavnom vrijednost britke negacije, rušilačku i polemičku vrijednost. Svi mi još uvijek čekamo Mesiju."12 Postoji i Desnica za kojeg su sva spomenuta pitanja relativna: “(...) čovjek je u razvoju svijeta, nastao veoma, veoma kasno. Tako kasno, da na mnogim stranama još nije ni nastao." ${ }^{3}$ Za takvog je Desnicu ključno pitanje je li "očovječenje čovjeka” uopće moguće: “(...) odakle i zašto to da su one provalije neljudskog, oni grdni kvantumi nečovještva, one nepregledne hekatombe ljudske koje smo doživjeli prije samih par decenija, ostavile, u stvari, tako plitkog i površnog traga u nama, u nama svima? Odakle to da se nešto što smo $s$ punim uvjerenjem mogli smatrati mementom, opomenom za čitava stoljeća, pokazalo kao ne baš naročito moćan memento ni za samih par decenija? I odakle uopće, proširujući to pitanje, (...) odakle uopće ljudsko iskustvo pa i najkrvavije tako kratko traje i tako malo važi." 14

Stariji od dvoje autora ovog Predgovora godine 1982. objavio je intervju s Pierreom Vilarom "Problemi izgradnje socijalne istorije". ${ }^{5}$ Jedan od doajena L'École des Hautes Études en Sciences Sociales, tada već umirovljen, završio je svoj iskaz - nastao, dakako, poštanskom razmjenom pitanja i odgovara - sljedećim riječima: "Želeo bih da se što je moguće više ljudi u svakom trenutku pita, suočeno sa svakim događajem, ne: to je dobro, to je loše, ovo volim, ovo mrzim itd., itd., nego: šta to predstavlja? Kuda nas to vodi? Uz pomoć analitičkog oruđa koje nije previše otupelo (koje koristi većina sveta, bilo da sluša radio, bilo da glasa). Tehničari - koji sve osvajaju - razmišljaju matematički, informatički; psiholozi - koji obično smatraju da im je dodeljena neka magična uloga - razmišljaju psihoanalitički. Trebalo bi, ali smo daleko od toga, da dovoljno mnoštvo sveta dovoljno naoružanog za tako nešto, misli ovaj svet historijski, naime sva društva zajedno u njihovoj dinamičnosti. Moje svakodnevno iskustvo u toj oblasti ne uliva mi poverenje. Želeo bih da je Vaše iskustvo vedrije od mog." ${ }^{16}$ Trideset i dvije godine otad su protekle. Starijem uredniku jedino ostaje nadati se da će se mlađima obistiniti ono što je njemu zaželio davne 1982. godine Pierre Vilar.

\section{Napomena.}

U knjizi Intelektualci i rat 1939.-1947. Zbornik radova s medunarodnog skupa Desničini susreti 2012. zabunom je s popisa recenzenata članaka ispušteno ime prof. dr. sc. Zvonka Kovača. Ispričavamo se recenzentu i čitateljima zbog ovog previda. Urednici Zbornika.

\footnotetext{
12 V. Desnica, Hotimično iskustvo. Knjiga druga, 79.

13 V. Desnica, Proljeća Ivana Galeba, 79.

14 V. Desnica, Hotimično iskustvo. Knjiga druga, 87.

15 "Problemi izgradnje socijalne istorije. Sa Pjer Vilarom razgovara Drago Roksandić", Marksistička misao, 1982., br. 4, $198-210$.

16 Isto, 210.
} 